\title{
Kasvintuhoojilla merkitystä ravinnekuormituksessa -Verkkolaikkutartunta vähentää ohran ravinteiden ottoa
}

\author{
Erja Huusela-Veistola, Marja Jalli, Kari Ylivainio, Eila Turtola, Riitta Lemola, Pentti Ruuttunen \\ MTT Kasvintuotannon tutkimus, 31600 Jokioinen, etunimi.sukunimi@mtt.fi
}

\section{Tiivistelmä}

Peltoviljelyn typpi- ja fosforikuormitus vesistöihin on yksi merkittävimmistä maatalouden aiheuttamista ympäristöhaitoista. Torjunta-aineiden käytöstä voi myös aiheutua päästöjä vesistöihin ja pieniä jäämiä elintarvikkeisiin, mutta Suomessa ravinnepäästöjä on pidetty suurempana ongelmana kuin torjuntaainejäämiä. Kasvinsuojelulla ja hallitulla torjunta-aineiden käytöllä on kuitenkin monitahoisia kytkentöjä maatalouden ympäristönsuojeluun.

Kasvinsuojelua ja kasvinsuojeluaineiden käyttöä on perinteisesti tarkasteltu vain kasvintuhoojien torjunnan ja viljelykasvin sadontuoton kannalta, eikä ole huomioitu kasvinsuojelun välillisiä vaikutuksia kasvin ravinteiden käyttöön ja sitä kautta ravinnekuormitukseen. Jos kasvinsuojelusta ei huolehdita, seurauksena voi olla kasvuston kunnon heikentyminen tai jopa täydellinen tuhoutuminen, jolloin osa kasvustolle suunnatuista ravinteista jää käyttämättä ja riski ravinnepäästöihin kasvaa.

Uutta perustietoa kasvintuhoojien merkityksestä kasvien ravinteiden ottoon tutkittiin astiakokeen avulla. Tutkimuksen tavoitteena oli selvittää, mikä on kasvintuhoojan vaikutus satokomponenttien mukana poistuviin ravinnemääriin ja -taseisiin. Kokeessa tutkittiin verkkolaikkutartunnan vaikutusta kasvin ravinteiden käyttöön kahdella ohralajikkeella (altis vs. resistentti). Astiakokeen tuloksia täydennettiin torjuntaainetarkastuksen yhteydessä tehdyn verkkolaikku/fungisidi -kenttäkokeen ravinneanalyyseillä ja ravinnetaselaskelmilla.

Tulosten mukaan alttiilla lajikkeella sadon mukana poistuvat typpi- ja fosforimäärät pienenivät 1926 \%, kun ohran verkkolaikkutartunta voimistui. Tämä osoitti, että kasvintuhoojien vioittamassa kasvustossa osa lannoitteista jää käyttämättä, ravinteita voi kertyä maahan ja kuormitusriski voi kasvaa. Verkkolaikkuvioituksen määrä ei vaikuttanut jyvien typpi- ja fosforipitoisuuksiin, joten ravinnetaselaskelmat voitaisiin ainakin tässä tapauksessa tehdä suhteellisen luotettavasti pelkkiin satomääriin perustuen.

Tuotantopanosten (lannoitteet, torjunta-aineet) käytön optimointi korostuu viljelytekniikoiden, ilmasto-olojen ja tuotantopanosten hintojen muuttuessa. Kasvukauden sääolosuhteet vaikuttavat sekä kasvien kasvuun että kasvintuhoojien määrään. Ilmaston muuttuessa leudot talvet lisäävät ravinteiden huuhtoutumisriskiä, ja toisaalta ne saattavat parantaa kasvintuhoojien talvehtimismahdollisuuksia. Tutkimuksen tulokset avaavat mielenkiintoisen näkökulman arvioitaessa kokonaisvaltaisesti kasvinsuojelun merkitystä maatalouden ympäristönsuojelussa.

\section{Asiasanat}

kasvinsuojelu, kasvitaudit, vesiensuojelu, ravinnepäästöt, ravinteet, ravinnetase, typpi, fosfori, ohra, verkkolaikku, taudinkestävyys 


\section{Johdanto}

Vesistöjen ja erityisesti Itämeren tilan heikkeneminen on ajankohtainen ympäristöongelma. Peltoviljelyn typpi- ja fosforikuormitus vesistöihin on yksi merkittävimmistä maatalouden aiheuttamista ympäristöhaitoista. Maatalouden vesistökuormituksen vähentämiseksi on käynnistynyt useita hankkeita, joissa kehitetään ja otetaan käyttöön tehostettuja maatalouden vesiensuojelutoimia.

Torjunta-aineiden käytöstä voi myös aiheutua päästöjä vesistöihin ja pieniä jäämiä elintarvikkeisiin, mutta Suomessa ravinnepäästöjä on pidetty suurempana ongelmana kuin torjunta-ainejäämiä. Kasvinsuojelulla ja hallitulla torjunta-aineiden käytöllä on kuitenkin monitahoisia kytkentöjä maatalouden ympäristönsuojeluun.

Kasvintuhoojat (kasvitaudit, tuhoeläimet ja rikkakasvit) alentavat satopotentiaalia monin tavoin. Kasvitaudit heikentävät fotosynteesitehokkuutta ja nopeuttavat lehtien vanhenemista ja kuolemista. Tuhoeläimet imevät kasvinesteitä, vähentävät biomassaa tai tuhoavat tärkeitä kasvinosia. Rikkakasvit kilpailevat valosta ja ravinteista. Kasvintuhoojaryhmien merkitys vaihtelee viljelykasveittain, mutta globaalien arvioiden mukaan noin kolmannes sadosta menetetään kasvintuhoojien vuoksi (Oerke 2006).

Muutokset viljelytekniikassa voivat lisätä kasvintuhoojien merkitystä. Esimerkiksi kevennetty muokkaus saattaa lisätä maa- ja kasvijätelevintäisten kasvitautien esiintymistä. Laaja monokulttuuriviljely ja vähentynyt viljelykierto kärjistävät tilannetta. Vaikka kasvinjalostuksen ansioista lajikkeiden satopotentiaali on kasvanut, ei satotaso käytännössä ole kuitenkaan noussut vastaavasti. Yhtenä syynä on pidetty kasvintuhoojien merkitystä (Peltonen-Sainio ym. 2007, Salo ym. 2008).

Kasvinsuojelua ja kasvinsuojeluaineiden käyttöä on perinteisesti tarkasteltu vain kasvintuhoojien torjunnan ja viljelykasvin sadontuoton kannalta, eikä kasvinsuojelun välillisiä vaikutuksia kasvin ravinteiden käyttöön ja sitä kautta ravinnekuormitukseen ole huomioitu. Jos kasvinsuojelusta ei huolehdita, seurauksena voi olla kasvuston kunnon heikentyminen tai jopa täydellinen tuhoutuminen, jolloin osa kasvustolle suunnatuista ravinteista jää käyttämättä ja riski ravinnepäästöihin kasvaa.

MTT:llä vuonna 2008 alkanut KARA (Kasvinsuojelu vesistöjen ravinnekuormituksen vähentäjänä) hanke selvittää kasvinsuojelun välillisiä vaikutuksia ravinnekuormitukseen. Hanke liittyy MTT:n Vesistöystävällinen maatalous -tutkimusohjelmaan.

Uutta perustietoa kasvintuhoojien merkityksestä kasvien ravinteiden ottoon saatiin astiakokeen avulla. Tutkimuksessa selvitettiin, mikä on kasvintuhoojan vaikutus satokomponenttien mukana poistuviin ravinnemääriin ja -taseisiin. Mallikasvina oli ohra ja kasvitautina ohranverkkolaikku (Pyrenophora teres). Astiakokeen tuloksia täydennettiin torjunta-ainetarkastuksen yhteydessä tehdyn kahden verkkolaikku/fungisidi -kenttäkokeen ravinneanalyyseillä ja ravinnetaselaskelmilla.

Ravinnetaseiden laskeminen on yleisesti käytetty menetelmä ravinteiden käytön tehokkuuden ja ravinnekuormitusriskin arviointiin. Ravinnetaselaskelma on maatalouden ympäristötuen yksi lisätoimenpide tukikaudella 2007-2013. Taselaskelmat tehdään typelle ja fosforille lohkokohtaisesti. Tässä tutkimuksessa oltiin kiinnostuneita siitä, miten kasvintuhoojien merkitys tulisi huomioida taselaskelmissa.

\section{Aineisto ja menetelmät}

\section{Astiakoe}

Astiakokeessa tutkittiin verkkolaikkutartunnan vaikutusta kasvin typen ja fosforin käyttöön kahdella ohragenotyypillä: A1) Rolfi (altis) ja A2) Rolfi ${ }^{6}$ x CI9819 (kestävä). Verkkolaikkutartunnan tasoja oli neljä: B1) ei tartuntaa (kontrolli), B2) keskimääräinen aikainen tartunta (1 tartutus orasvaiheessa), B3) keskimääräinen myöhäinen tartunta (1 tartutus lippulehtivaiheessa) ja B4) voimakas tartunta (2 tartutusta, oras- ja lippulehtivaihe). Toistoja oli neljä. Koeasetelma oli rivi-sarake (row-column) -malli, jonka mukaisesti koeastiat laitettiin 8 riviin ja 4 sarakkeeseen. Koe toteutettiin kasvihuoneessa keväällä 2008.

Maa-aines astiakokeeseen haettiin pellolta Jokioisten Rehtijärveltä tammikuussa 2008. Maasta tehtiin viljavuusanalyysi, jonka perusteella laskettiin kokeessa käytettävien lannoitteiden määrät. Maa seulottiin 6-14 mm:n seuloilla. Seulotusta maasta otettiin näyte maalajianalyysiä varten.

Koe tehtiin n. 3,5 litran (läpimitta 18,4 cm) muovipurkeissa, joihin punnittiin 2,8 kg maata. Ravinneliuokset sekoitettiin koko maatilavuuteen erillisessä astiassa. Ravinnemäärät purkkia kohti esitetään taulukossa 1. Koemaata ei kalkittu, koska sen pH oli jo valmiiksi 6,5.

Täyssato-valmisteella (karboksiini + imatsaliili) peitattu tasakokoinen siemen kylvettiin peruslannoitettuun multaan 8.2.2008. Kylvömäärä oli 13 siementä/purkki. Orastumisen jälkeen kuhunkin purkkiin 
jätettiin 10 kasvia. Purkit kasteltiin 2-3 kertaa viikossa samalla vesimäärällä. Kasvatusolot olivat normaalit viljojen kasvatusolot: lämpötila $18-20^{\circ} \mathrm{C}$ (päivä), $12{ }^{\circ} \mathrm{C}$ (yö), valojaksotus $16 \mathrm{~h} / 8 \mathrm{~h}$. Kasvit tuettiin tukikepein ennen ensimmäistä kasvitautitartutusta.

Kasvihuone sumutettiin ennen kasvitautitartutusta niin, että huoneen suhteellinen ilmankosteus oli $100 \%$. Kasvitautitartukkeena oli ohranverkkolaikkuisolaatista pt87 valmistettu itiösuspensio, jota annosteltiin orasvaiheessa (25.2.2008) 80000 itiötä ja lippulehtivaiheessa (31.3.2008) 200000 itiötä purkkia kohti. Tartuntatehoa parannettiin sumutuksella, joka piti kosteusolot kasvitaudille optimaalisena.

Verkkolaikkuoireiden määrä tarkistettiin NIAB-asteikolla (NIAB 1985) 10 vrk:n kuluttua 1. tartutuksesta, juuri ennen 2. tartutusta, 10 vrk 2. tartutuksen jälkeen sekä maitotuleentumisasteella 11.4.2008. Sato määritettiin tuleentuneesta kasvustosta, josta otettiin samalla näytteet ravinneanalyyseihin sekä jyvistä että oljista 27.5.2008.

Taulukko 1. Astiakokeessa käytetyt ravinnemäärät.

\begin{tabular}{llc}
\hline ravinne & yhdiste & ravinnemäärä/astia mg \\
\hline $\mathrm{N}$ & $\mathrm{NH}_{4} \mathrm{NO}_{3}$ & 1500 \\
$\mathrm{~K}$ & $\mathrm{KCl}$ & 1500 \\
$\mathrm{P}$ & $\mathrm{Na}_{2} \mathrm{HPO}_{4} * 2 \mathrm{H}_{2} \mathrm{O}$ & 400 \\
$\mathrm{Mg}$ & $\mathrm{MgSO}_{4} * 6 \mathrm{H}_{2} \mathrm{O}$ & 200 \\
$\mathrm{~S}$ & väk. $\mathrm{H}_{2} \mathrm{SO}_{4}$ & 300 \\
$\mathrm{Ca}$ & $\mathrm{CaCl}_{2}$ & 400 \\
$\mathrm{Fe}$ & $\mathrm{FeSO}_{4} * 7 \mathrm{H}_{2} \mathrm{O}$ & 10 \\
$\mathrm{Mn}$ & $\mathrm{MnSO}_{4} * \mathrm{H}_{2} \mathrm{O}$ & 10 \\
$\mathrm{Zn}$ & $\mathrm{ZnSO}_{4} * 7 \mathrm{H}_{2} \mathrm{O}$ & 10 \\
$\mathrm{Cu}$ & $\mathrm{CuSO}_{4} * 5 \mathrm{H}_{2} \mathrm{O}$ & 5 \\
$\mathrm{~B}$ & $\mathrm{H}_{3} \mathrm{BO}_{3}$ & 1 \\
$\mathrm{Mo}$ & $\mathrm{Na}_{2} \mathrm{MoO}_{4} * 2 \mathrm{H}_{2} \mathrm{O}$ & 1 \\
$\mathrm{Cl}$ & $\mathrm{NaCl} \mathrm{CaCl}_{2}$ & 700 \\
$\mathrm{Na}$ & $\mathrm{NaCl}$ & 20 \\
\hline
\end{tabular}

\section{Kenttäkokeet}

Astiakokeen tuloksia täydennettiin kahden torjunta-ainetarkastuksen yhteydessä tehdyn verkkolaikuntorjunta/fungisidi -kenttäkokeen ravinneanalyyseillä. Kokeissa oli mukana useampi kasvitautien torjunta-aine ja käyttömäärä, joista ravinneanalyyseihin valittiin vuonna 2008 kaksi erityyppistä ainetta (fungisidi 1: Proline, protiokonatsoli 200 g/ha, ja fungisidi 2: Bixafen + Protiokonatsoli) ja kontrolli. Vuoden 2007 kokeesta mukana oli vain toinen em. fungisidivalmisteista (fungisidi 1: Proline). Jokioisissa toteutettujen kenttäkokeiden viljelytekniset tiedot löytyvät taulukosta 2. Kummassakin kokeessa kustakin koejäsenestä oli neljä toistoa. Kasvitautivioituksen määrä ja sato määritettiin NIAB-asteikolla (NIAB 1985). Lajitellusta sadosta tehtiin N- ja P-analyysit.

Taulukko 2. Fungisidikenttäkokeissa käytetyt viljavuusanalyyseihin perustuvat lannoitemääät sekä kokeiden kylvö-, käsittely-, havainto- ja puintipäivämäärät. Vuoden 2008 koe ravinteikkaalla eloperäisellä maalla.

\begin{tabular}{lcc}
\hline Toimenpide & $\mathbf{2 0 0 7}$ & $\mathbf{2 0 0 8}$ \\
\hline Lannoitus, kg/ha* & & \\
$\quad \mathrm{N}$ & 85 & 39 \\
$\mathrm{P}$ & 13 & 6 \\
$\mathrm{~K}$ & 34 & 17 \\
& & \\
Kylvö & 14.5 .07 & 13.5 .08 \\
Kasvitautitorjunta & 21.6 .07 & 16.6 .08 \\
Kasvitautihavainnot & 3.8 .07 & 4.8 .08 \\
Puinti & 16.8 .07 & 22.8 .08 \\
\hline * Vuonna 2007 käytetty lannoite Kevätviljan Y3 (424 kg/ha N-P-K 20-3-8) \\
ja vuonna 2008 Pellon Y3 (185 kg/ha N-P-K 21-3-9)
\end{tabular}




\section{Tulokset}

\section{Astiakoe}

Oletusten mukaisesti verkkolaikkuvioitus oli voimakkaampaa alttiilla Rolfi-lajikkeella, jossa kaksi tartutuskertaa tuottivat voimakkaan verkkolaikkutartunnan. Kestävällä genotyypillä verkkolaikun vioitukset jäivät pieniksi kaikilla tartutustavoilla (Kuva 1, Taulukko 3).

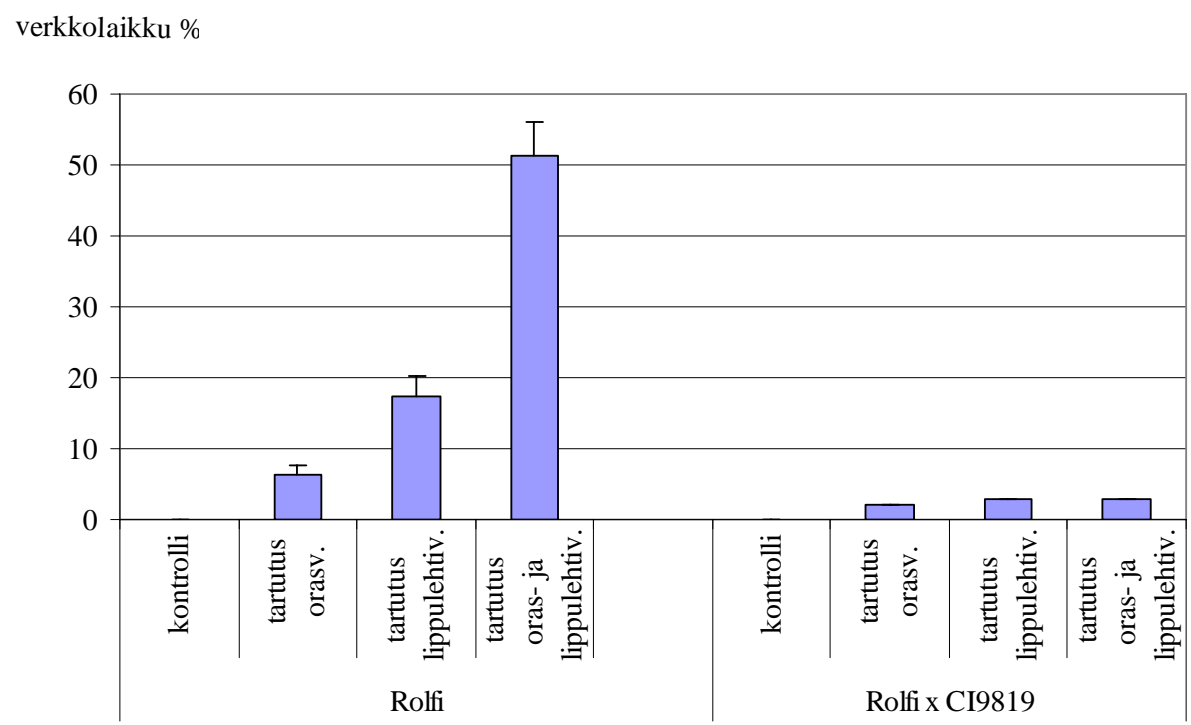

Kuva 1. Verkkolaikkuvioituksen voimakkuus ohran maitotuleentumisasteella eri käsittelyissä astiakokeessa.

Taulukko 3. Verkkolaikkutartunta-\% astiakokeessa sekä jyväsato, kokonais- ja olkibiomassa sekä 1000 siemenen paino keskimäärin käsittelyittäin. Alla koetekijöiden tilastollisesti merkitsevät erot.

\begin{tabular}{|c|c|c|c|c|c|}
\hline & $\begin{array}{c}\text { verkko- } \\
\text { laikku-\% }\end{array}$ & $\begin{array}{c}\text { jyväsato } \\
\text { g/astia }\end{array}$ & $\begin{array}{c}\text { kokonais- } \\
\text { biomassa g }\end{array}$ & $\begin{array}{c}\text { oljen } \\
\text { biomassa g }\end{array}$ & 1000-sp g \\
\hline \multicolumn{6}{|l|}{ Rolfi } \\
\hline kontrolli & 0.0 & 23.3 & 59.7 & 36.5 & 42.5 \\
\hline tartutus orasv. & 6.3 & 20.6 & 58.1 & 37.6 & 44.8 \\
\hline tartutus lippulehtiv. & 17.5 & 20.5 & 58.3 & 37.8 & 42.4 \\
\hline tartutus oras- ja lippulehtiv. & 51.3 & 17.5 & 54.3 & 36.8 & 44.8 \\
\hline \multicolumn{6}{|l|}{ Rolfi x CI9819 } \\
\hline kontrolli & 0.0 & 17.7 & 60.4 & 42.7 & 42.2 \\
\hline tartutus orasv. & 2.0 & 16.2 & 58.4 & 42.2 & 41.9 \\
\hline tartutus lippulehtiv. & 3.0 & 17.0 & 57.0 & 40.1 & 41.9 \\
\hline tartutus oras- ja lippulehtiv. & 3.0 & 17.3 & 59.6 & 42.3 & 42.7 \\
\hline \multicolumn{6}{|l|}{ Tilastolliset erot } \\
\hline lajike & $* * \star$ & ** & $\circ$ & *** & $\star * *$ \\
\hline vl-tartutus & $* \star \star$ & & * & & * \\
\hline lajike x vl-tartutus & $\star * \star$ & & & & * \\
\hline
\end{tabular}

Alttiilla Rolfi-lajikkeella jyväsato väheni, kun verkkolaikkutartunta voimistui. Ero ei ollut kuitenkaan tilastollisesti merkitsevä (Taulukko 3), vaikkakin kontrolli erosi voimakkaasta tartutuksesta $\left(\mathrm{P}=0,025^{*}\right)$. Rolfin jyväsato oli merkitsevästi suurempi ja olkibiomassa pienempi kuin ohran verkkolaikkua kestävällä Rolfi ${ }^{6}$ x CI9819 -genotyypillä. Verkkolaikkutartunta vähensi kokonaisbiomassaa kummallakin lajikkeella (Taulukko 3).

Verkkolaikkuvioituksen voimakkuudella ei ollut vaikutusta jyvien $\mathrm{N}$ - ja P -pitoisuuksiin (Taulukko 4). Sen sijaan Rolfi-lajikkeella oljen N- ja P-pitoisuus nousi, kun verkkolaikkutartunta voimistui (Taulukko 4). Jyvien mukana poistuvan fosforin määrä väheni merkitsevästi verkkolaikulle alttiilla Rolfilla, kun verkkolaikkuvioituksen määrä kasvoi, mikä selitti lajikkeen ja verkkolaikun välisen yhdysvaikutuksen 
(Taulukko 4). Myös jyvien mukana poistuva kokonaistyppimäärä väheni verkkolaikkuvioituksen voimistuessa, mutta ero oli suuntaa antava vain analysoitaessa verkkolaikulle altis Rolfi -lajike erikseen $\left(\mathrm{P}=0,096^{\circ}\right)$. Olkiin sitoutuneen typen ja fosforin määrät olivat pienemmät Rolfilla kuin Rolfi ${ }^{6}$ x CI9819genotyypillä. Olkiin sitoutunut typpimäärä kasvoi, kun kasvustossa oli verkkolaikkua, mutta fosforimäärissä ei havaittu tilastollisesti merkitsevää eroa kasvitautikäsittelyjen välillä (Taulukko 4).

Taulukko 4. Jyvien ja oljen N- ja P-pitoisuudet, maan P-pitoisuus sekä jyvien ja olkien mukana poistuneet N- ja P-määrät astiakokeessa. Alla koetekijöiden tilastollisesti merkitsevät erot.

\begin{tabular}{|c|c|c|c|c|c|c|c|c|c|}
\hline & \multicolumn{4}{|c|}{ Ravinnepitoisuudet } & \multicolumn{5}{|c|}{ Sadon mukana poistuneet ravinteet } \\
\hline & $\begin{array}{c}\text { jyvissä } \\
\text { N \% ka }\end{array}$ & $\begin{array}{c}\text { jyvissä } \\
\text { P g/kg }\end{array}$ & $\begin{array}{c}\text { oljessa } \\
\text { N \% ka }\end{array}$ & $\begin{array}{l}\text { oljessa } \\
\text { P g/kg }\end{array}$ & $\begin{array}{l}\text { maassa } \\
\text { P mg/g }\end{array}$ & $\begin{array}{c}\text { jyvä } \\
\text { Ntot mg }\end{array}$ & $\begin{array}{c}\text { jyvä } \\
\text { Ptot mg }\end{array}$ & $\begin{array}{c}\text { olki } \\
\text { Ntot mg }\end{array}$ & $\begin{array}{c}\text { olki } \\
\text { Ptot mg }\end{array}$ \\
\hline \multicolumn{10}{|l|}{ Rolfi } \\
\hline kontrolli & 2.8 & 5.8 & 0.9 & 1.8 & 52.8 & 652 & 135 & 337 & 66 \\
\hline tartutus orasv. & 2.9 & 5.8 & 1.0 & 2.1 & 50.7 & 601 & 118 & 374 & 79 \\
\hline tartutus lippulehtiv. & 2.8 & 5.2 & 1.1 & 2.2 & 56.9 & 562 & 106 & 433 & 82 \\
\hline tartutus oras- ja lippulehtiv. & 3.1 & 5.7 & 1.2 & 2.4 & 54.8 & 529 & 99 & 452 & 87 \\
\hline \multicolumn{10}{|l|}{ Rolfi x CI9819 } \\
\hline kontrolli & 2.7 & 5.3 & 1.0 & 2.1 & 53.8 & 468 & 92 & 435 & 91 \\
\hline tartutus orasv. & 2.8 & 5.7 & 1.1 & 2.2 & 56.6 & 439 & 90 & 446 & 91 \\
\hline tartutus lippulehtiv. & 2.9 & 5.5 & 1.0 & 2.2 & 54.0 & 483 & 93 & 412 & 86 \\
\hline tartutus oras- ja lippulehtiv. & 2.7 & 5.2 & 1.1 & 2.3 & 54.3 & 462 & 90 & 459 & 95 \\
\hline \multicolumn{10}{|l|}{ Tilastolliset erot } \\
\hline lajike & * & & & & & $\star \star \star$ & $\star \star \star *$ & * & ** \\
\hline vl-tartutus & & & $\star \star \star$ & * & & & * & $\circ$ & \\
\hline lajike x vl-tartutus & & & $\star \star$ & & & & * & & \\
\hline
\end{tabular}

\section{Kenttäkokeet}

Fungisidikäsittelyt vähensivät ohranverkkolaikkuvioituksen määrää ja paransivat satoa kummassakin kenttäkokeessa (Taulukko 5). Sadon N- ja P-pitoisuuksiin fungisidikäsittelyllä tai verkkolaikun määrällä ei ollut merkitsevää vaikutusta. Sadon mukana poistuneet ravinnemäärät (kokonais-N ja -P kg/ha) olivat suuremmat fungisidikäsitellyissä kuin kontrollikoejäsenissä . Kasvitautitorjunta paransi ravinnetasetta, koska torjunnan avulla ohranverkkolaikku pysyi kurissa ja saatiin parempi sato. Ero oli suurempi vuonna 2008, jolloin ohran verkkolaikkua esiintyi runsaammin kuin vuonna 2007.

Taulukko 5. Verkkolaikun määrä, sato, jyvien N- ja P-pitoisuudet sekä sadon mukana poistuneet N- ja P-määrät kahdessa verkkolaikuntorjuntakokeessa Jokioisissa. Fungisidi1: Proline; fungisidi2: Bixafen + Protiokonatsoli.

\begin{tabular}{ccccc}
\hline vuosi & kontrolli & fungisidi1 & fungisidi2 & Tilastolliset erot \\
\hline 2007 & & & & \\
verkkolaikku-\% & 26.3 & 13.1 & - & $<0.001^{* * *}$ \\
sato (kg/ha) & 6299 & 6899 & - & $0.035^{*}$ \\
N (\% kuiva-aineesta) & 1.86 & 1.90 & - & 0.475 \\
P (mg/kg) & 4.11 & 4.15 & - & 0.376 \\
kokonais-N (kg/ha) & 117.0 & 134.0 & - & $0.071^{\circ}$ \\
kokonais-P (kg/ha) & 25.9 & 29.3 & - & $0.007 * *$ \\
& & & & \\
2008 verkkolaikku-\% & 75.0 & 20.0 & 5.5 & $<0.001 * * *$ \\
sato (kg/ha) & 5769 & 6948 & 7972 & $0.002 * *$ \\
N (\% kuiva-aineesta) & 1.64 & 1.56 & 1.55 & 0.258 \\
P (mg/kg) & 3.66 & 3.66 & 3.67 & 0.666 \\
kokonais-N (kg/ha) & 94.2 & 109.0 & 124.3 & $0.023 *$ \\
kokonais-P (kg/ha) & 21.1 & 24.9 & 29.3 & $0.007 * *$ \\
\hline
\end{tabular}




\section{Tulosten tarkastelu}

Tulosten mukaan ohrasadon mukana poistuvat typpi- ja fosforimäärät pienenivät, kun ohran verkkolaikkutartunta voimistui. Tämä osoitti selvästi, että kasvintuhoojien vioittamassa kasvustossa lannoitteissa annettujen ravinteiden hyväksikäyttö laskee, ravinteita voi kertyä maahan ja kuormitusriski voi kasvaa. Verkkolaikkuvioituksen määrä ei vaikuttanut jyvien typpi- ja fosforipitoisuuksiin, joten ravinnetaselaskelmat voitaisiin ainakin tässä tapauksessa tehdä suhteellisen luotettavasti pelkkiin satomääriin perustuen.

Tulostemme perusteella kasvitautien torjunnalla voidaan tehostaa ohran ravinteiden käyttöä. Vastaavia tuloksia typen osalta on saatu vehnän kasvitautien torjunnalla (Dimmock \& Gooding 2002, Delin ym. 2009). Viljelykasvuston pitäminen kunnossa pidentää fotosynteesijaksoa ja parantaa ravinteiden käyttöä. Kasvinsuojelun avulla estetään tai vähennetään kasvintuhoojista aiheutuvia satotappioita. Kasvinsuojelun ansioista satotaso ja sadon mukana poistunut ravinnemäärä ovat selvästi suurempia kuin kasvintuhoojien vioittamassa kasvustossa. Torjunnalla voidaan vaikuttaa myös sadon laatuun (Gooding ym. 2000).

Astiakoe ilmensi selkeät erot kahden eri ohragenotyypin välillä. Verrattavina oli Suomessa yleisesti viljelty Rolfi-lajike sekä genotyyppi, jossa Rolfi-lajikkeeseen oli risteyttämällä siirretty verkkolaikunkestävyys etiopialaisesta CI9819-ohrasta. Lajikkeen ominaisuudet osoittautuivat merkittäväksi tekijäksi jyvien ja olkisadon typpi- ja fosforisadossa. Tämä oli kuitenkin suorassa suhteessa lajikkeen sadontuottokykyyn.

Lajikevalinnoilla voidaan vaikuttaa lannoiteravinteiden hyötysuhteeseen suoraan valitsemalla viljelyolosuhteisiin parhaiten sopivia lajikkeita (El Bassan 1998) tai välillisesti valitsemalla kasvitaudeille vastustuskykyisiä lajikkeita (Wolfe ym. 2008).

Viljan valkuais- ja typpipitoisuutta ja niiden vaihteluun vaikuttavia tekijöitä on kasvinsuojelun näkökulmasta tutkittu enemmän kuin fosforin merkitystä. Fosforin merkitys sadontuotannon kannalta kuitenkin korostuu tulevaisuudessa, koska varannot ovat maailmanlaajuisesti vähenemässä. Toisaalta fosforia on suomalaisissa peltomaassa paikoin ylimäärin aiemman lannoituksen seurauksena (Uusitalo ym. 2007, Valkama ym. 2009).

Viljelykasvien tutkimuksessa huomio kiinnittyy yleensä vain kasvin maanpäälliseen osaan. Hyväkuntoinen juuristo on kuitenkin avaintekijä ravinteiden otossa ja hyväksikäytössä. Kasvintuhoojien vioitukset kasvin maanpäällisissä osassa heijastuvat usein myös juurten kasvuun. Osa kasvintuhoojista vioittaa myös ainoastaan juuria. Nopea taimettuminen ja kasvuun lähtö edesauttavat kasvuston kehitystä ja ravinteiden käyttöä sekä vähentävät ravinnepäästöjen riskiä kasvukauden alussa. Elinvoimaisella kylvösiemenellä ja tarpeenmukaisilla kasvinsuojelutoimilla taataan osaltaan hyvä satopotentiaali. Kasvukauden olosuhteista johtuen satopotentiaalin realisoituminen vaihtelee vuosittain, samoin sadon valkuaispitoisuus.

\section{Johtopäätökset}

Tulokset osoittivat, että kasvintuhoojien vioittamassa kasvustossa osa lannoitteista jää käyttämättä, joten ravinteita voi ajan oloon kertyä maahan ja kuormitusriski voi kasvaa. Ravinteiden ja lannoitteiden tehokas hyväksikäyttö on tärkeää sekä taloudellisesti että ympäristön kannalta. Tuotantopanosten (lannoitteet, torjunta-aineet) käytön optimointi korostuu viljelytekniikoiden, ilmasto-olojen ja tuotantopanosten hintojen muuttuessa. Kasvukauden sääolosuhteet vaikuttavat sekä kasvien kasvuun että kasvintuhoojien määrään. Ilmaston muuttuessa leudot talvet lisäävät ravinteiden huuhtoutumisriskiä, ja toisaalta ne saattavat parantaa kasvintuhoojien talvehtimismahdollisuuksia. Tutkimuksen tulokset avaavat mielenkiintoisen näkökulman arvioitaessa kokonaisvaltaisesti kasvinsuojelun merkitystä maatalouden ympäristönsuojelussa.

\section{Kiitokset}

Kiitokset kaikille KARA-hankkeeseen osallistuneille.

\section{Kirjallisuus}

Delin, S., Nyberg, A., Linden, B., Ferm, M., Torstensson, G., Lerenius, C. \& Gruvaeus, I. 2008. Impact of crop protection on nitrogen utilization and losses in winter wheat production. European Journal of Agronomy 28: 361-370. Dimmock, J.P.R. \& Gooding, M.J. 2002. The influence of foliar diseases, and their control by fungicides, on the protein concentration in wheat grain: a review. Journal of Agricultural Science 138: 349-366.

Gooding, M.J., Dimmock, J.P.R., France, J. \& Jones, S.A. 2000. Green leaf area decline of wheat flag leaves: the influence of fungicides and relationships with mean grain weight and grain yield. Annals of Applied Biology 136:7784. 
El Bassam, N. 1998. A concept of selection for 'low input' wheat varieties. Euphytica 100: 95-100. NIAB (1985). Disease Assessment Manual for Crop Variety Trials. National Institute of Agricultural Botany: Cambridge.

Oerke, E.-C. 2006. Crop losses to pests. Journal of Agricultural Science 144: 31-43.

Peltonen-Sainio, P., Jauhiainen, L. \& Hannukkala, A. 2007. Declining rape seed yields in Finland: how, why and what next? Journal of Agricultural Science 145: 587-598.

Salo, T., Jauhiainen, L., Kartio, M. 2008. Viljasadon määrä ja laatu ympäristöohjelmakausien aikana. In: Eila Turtola ja Riitta Lemola (toim.). Maatalouden ympäristötuen vaikutukset vesistökuormitukseen, satoon ja viljelyn talouteen 2000-2006(MYTVAS 2). Maa- ja elintarviketalous 120: p. 72-77.

Uusitalo, R., Turtola, E., Grönroos, J., Kivistö, J., Mäntylahti, V., Turtola, A., Lemola, R., Salo, T. 2007. Finnish trends in phosphorus balances and soil test phosphorus. Agricultural and Food Science 16, 4: 301-316. [

Valkama, E., Uusitalo, R., Ylivainio, K., Virkajärvi, P., Turtola, E. 2009. Phosphorus fertilization: a metaanalysis of 80 years of research in Finland. Agriculture, ecosystems \& environment 130, 3-4: 75-85. doi:10.1016/j.agee.2008.12.004

Wolfe, M. S., Baresel, J.P., Desclaux, D., Goldringer, I., Hoad, S., Kovacs, G., Löschenberger, F., Miedaner, T., Østergård, H., Lammerts van Bueren, E.T. 2008. Developments in breeding cereals for organic agriculture. Euphytica 163: 323-34. 